\title{
Original article \\ Effect of Nitrendipine, Diltiazem and Verapamil on psychomotor performance in human volunteers
}

\begin{abstract}
Tamboli SB
\section{$\underline{\text { Abstract }}$}

Background: Calcium channel blockers are amongst the commonly used drugs in the treatment of cardiovascular disorders. They produce their action by blocking voltage regulated calcium channels. Methodolgy: Present study evaluated the effects of three structurally dissimilar calcium channel blockers Nitrendipine (a dihydropyridine) in a single dose of $10 \mathrm{mg}$ and $20 \mathrm{mg}$, Diltiazem (a benzothiazepine) in a single dose of 30 $\mathrm{mg}$ and $60 \mathrm{mg}$ and Verapamil (a phenylalkylamine) in a single dose of $40 \mathrm{mg}$ and $80 \mathrm{mg}$ on psychomotor performance in human volunteers. For evaluation of psychomotor performance, the tests used were arithmetic ability, verbal learning, letter cancellation, digit symbol substitution and card sorting test. Results: Nitrendipine both in low dose (10mg) and high dose (20mg) as well as Diltiazem in high dose (60mg) and Verapamil in high dose (80mg) were found to impair the psychomotor performance in human volunteers to a statistically significant extent in all the tests employed except letter cancellation test. Whereas Diltiazem in low dose (30mg) and Verapamil in low dose (40mg) showed statistically significant impairment of psychomotor performance using arithmetic ability, verbal learning, and digit symbol substitution test. Conclusion: Thus calcium channel blockers namely Nitrendipine, Diltiazem and Verapamil significantly impaired the psychomotor performance of human volunteers in our study.
\end{abstract}

Key words: calcium channel blockers, psychomotor performance

\section{Introduction}

Calcium channel antagonists constitute a heterogenous class of agents with unrelated structural, electrophysiological and pharmacological properties ${ }^{1}$.

Structurally different Calcium channel blockers including Nitrendipine, Diltiazem and Verapamil show varied sensitivity towards Calcium channels at different sites in the body. They have been demonstrated in a variety of tissues including brain ${ }^{2,3}$.

Some of the Calcium channel blockers namely Nifedipine, Diltiazem and Verapamil have been reported to block Calcium channels in the neurons. Blockade of neuronal Calcium channels might be responsible for the inhibition of seizure spread ${ }^{4}$. Similarly they may interfere with calcium mediated neuronal activities namely propagation of impulses and release of neurotransmitters .

In addition to their Calcium channel blocking effects in the neurons, they have a direct effect on the central nervous system ${ }^{4,6}$. At therapeutic doses Nifedipine and Diltiazem show penetration into the brain $^{6}$.
Doran et al (1985) ${ }^{7}$ have measured levels of Verapamil and the active metabolite Norverapamil in cerebrospinal fluid in schizophrenic patients.

Besides cardiovascular disorders, calcium channel antagonists are used in neurological disorders like migraine, subarachnoid hemorrhage, cerebrovascular accidents, vertigo, intractable hiccough and epilepsy ${ }^{8}$.

Calcium channel blockers also have a place in the treatment of psychiatric disorders like maniac depressive psychosis, depression, schizophrenia and tardive dyskinesia ${ }^{5}$.

Jaguste, Dadkar and Dhar (1990) ${ }^{9}$ showed that Nifedipine and Verapamil impaired psychomotor performance in human subjects.

With this background the present study was undertaken to evaluate the effects of three structurally dissimilar Calcium channel blockers Nitrendipine (second generation Calcium channel blocker) Diltiazem and Verapamil in single low and high dosages on psychomotor performance in normal healthy human

Corresponds to: Saleem Basha Tamboli, Associate Professor and Head, Dept. of Pharmacology

Dr. Shankarrao Chavan Govt. Medical College, Nanded, Maharashtra $\underline{\boldsymbol{E} \text {-mail: }}$ microbiopharma@yahoo.com 
volunteers using conventional psychomotor performance tests.

\section{Material \& Methods}

The present study was carried out in clinical pharmacology division- Department of pharmacology. It was a single blind randomized trial. Fifteen normal healthy human volunteers in the age group of 18 to 21 years of either sex having a body weight that did not deviate from the normal by more than $10 \%$ were included in the study.

Those volunteers who have history of drug allergy, diabetes mellitus, tuberculosis, asthma, epilepsy, HBV and HIV positive cases, gastrointestinal, renal, hepatic and cardiac diseases were excluded from the study.

Informed written consent was obtained from all the volunteers after explaining the study pattern and related hazard involving drug allergies and possible adverse reactions. The study was approved by institutional ethical committee of Government medical college and Hospital.

Routine investigations of each volunteer such as complete hemogram, urine analysis, random blood sugar, liver function test(serum bilirubin, SGOT, SGPT), kidney function tests( blood urea, serum creatinine), electrocardiogram, HBV and HIV testing, X-ray chest were carried out before the study.

Prior to the study sessions all volunteers underwent detail medical examination. Volunteers selected for the study had no clinically significant abnormal findings.

The volunteers were well versed with the various psychomotor performance tests, they were given practice till consistent scores were obtained for all the tests to be performed prior to the study day.

On the study day the volunteers were asked to come in the clinical pharmacology division- Department of Pharmacology at 8 a.m. on an empty stomach and zero hour (before giving drug) readings were taken. Following this they were provided a light breakfast. The drugs used were tablet Nitrendipine ( Nitrepin) 10mg single dose, tablet Nitrendipine ( Nitrepin) 20mg single dose, tablet Diltiazem (Dilzem) 30mg single dose, tablet Diltiazem (Dilzem) 60mg single dose, tablet Verapamil (Calaptin) 40mg single dose, tablet Verapamil (Calaptin) 80mg single dose.

The drugs were administered in a single dose with $50 \mathrm{ml}$ of water orally to the volunteers according to a randomized chart. All the psychomotor tests were performed at ${ }^{1,2,3,4,5,6,7}$ and 8 hours (post dose) after drug administration.

Standard lunch was provided four hours after the drug was given to the volunteers.

After the washout period of one week the same procedure was repeated and readings were taken pre and post dose respectively for each drug groups.

\section{Psychomotor Performance Tests Used:}

Following are the details of psychomotor performance tests used.

\section{Arithemetic Ability test:}

Summation test was performed to test arithmetic ability. For this purpose eight vertical columns (sums) were prepared, each column containing ten figures (between 10 and 99) which were to be added up. Score - The number of wrong sums were recorded $^{10}$.

Verbal Learning test:

In this test 10 words were shown to the volunteers. One word at a time for 5 seconds at one second intervals. After the final word was presented, a 6 digit number was shown (to eliminate a recency effect). The volunteers were asked to write down that number and as many words as they could remember in 60 seconds ${ }^{11}$.

Score - The score being the total number of correctly recalled words in 60 seconds.

Letter Cancellation test:

In this test, the volunteer cancels particular letter (digit) in a line of numbers, the frequency of letter being 40 in 400 numbers. The volunteer was asked to cancel a particular letter by a single vertical stroke.

Score - The score being the time taken to cancel particular letters $^{12,13}$.

Digital Symbol Substitution test:

In this test 10 symbols were taken to represent 10 digits (0 to 9 ). The symbols and digits are randomly 
tabulated and repeated in different sequences many times. The volunteer has to match as many digits to the symbols as he can over a time period of 2 minutes.

Score - The scores being the total number of correctly substituted digits in two minutes ${ }^{12,14}$.

Card Sorting test:

For this test it was initially confirmed that all the volunteers were familiar with playing cards. The volunteers were shown a set of four cards arranged randomly. They were allowed to view each card for a period of 10 seconds. The set of cards was shown three times in succession without changing the times for viewing. Immediately after they were asked to remove all the same four cards shown by the tester in one minute ${ }^{9}$.

Score - The score being the total number of correctly removed cards in one minute.

\section{Version:}

Volunteers received different set of versions at each reading for each test. 15 such versions were prepared for each test.

\section{Sample size:}

Fifteen volunteers were used for individual drug group (Nitrendipine, Diltiazem, Verapamil) for low and high doses respectively. Total 45 volunteers were enrolled in the study.

\section{Statistical Analysis:}

The changes in the psychomotor performance observed after single drug administration to that with basal value ( before giving drug) were analyzed by paired student's ' $t$ ' test.

To compare the alteration in the psychomotor performance for low dose and high dose of individual drug group, unpaired student's' $t$ ' test was applied.

Statistical significance was indicated by conventional symbols.

** $(\mathrm{P}<0.05)$

NS $(P>0.05)$ not significant

\section{Results and Discussion}

Cardiovascular disease is a major health problem that affects a large segment of adult population in world, a significant portion of the adult work force may be expected to be under treatment with cardiovascular medications including Calcium channel blockers.
The present study evaluated the effects of Nitrendipine $10 \mathrm{mg}$ and $20 \mathrm{mg}$, Diltiazem 30mg and $60 \mathrm{mg}$ and Verapamil 40mg and $80 \mathrm{mg}$ on psychomotor performance in normal healthy human volunteers using conventional psychomotor performance tests.

Psychomotor performance tests were selected in such a manner that arithmetic ability, short term memory, concentration, learning, discrimination and motor activity were evaluated.

Results of the present study showed Nitrendipine in single low dose $10 \mathrm{mg}$ as well as in single high dose 20mg significantly impaired psychomotor performance in volunteers using arithmetic ability test, verbal learning test, digital symbol substitution test and card sorting test $(\mathrm{P}<0.05)$.

Experimental evidence suggests that Nitrendipine produces impaired psychomotor activity in rats ${ }^{15}$.

Impaired learning and memory with Nifedipine has been reported in some elderly hypertensive patients by skinner et al $(1992)^{16}$.

David Spurgeon (1999) ${ }^{17}$ and Maxwell, Hogan and Ebly (1999) ${ }^{18}$ in their study have shown that declines in cognitive function were significantly greater among elderly people using calcium channel blockers(Nifedipine, Diltiazem and Verapamil) than among those using other antihypertensive agents. Similarly Payne R(1990) ${ }^{19}$ reported that analgesic adjuvants ( coanalgesics) like Calcium channel blockers may impair psychomotor functioning.

In the present study Diltiazem in single low dose $30 \mathrm{mg}$ as well as Verapamil in single low dose 40mg showed significant impairment of psychomotor performance in volunteers using arithmetic ability test, verbal learning test, digital symbol substitution test $(\mathrm{P}<0.05)$.

Diltiazem in single high dose $60 \mathrm{mg}$ as well as Verapamil in single high dose $80 \mathrm{mg}$ showed significant impairment psychomotor performance in volunteers using arithmetic ability test, verbal learning test, digital symbol substitution test and card sorting test $(\mathrm{P}<0.05)$. 
The above results of Diltiazem and Verapamil are consistent with the results obtained by Jaguste, Dadkar and Dhar (1990) ${ }^{9}$, David Spurgeon (1999) ${ }^{17}$, Maxwell, Hogan and Ebly (1999) ${ }^{18}$ and Payne R $(1990)^{19}$.

Though low as well as high dose of Nitrendipine, Diltiazem and Verapamil significantly impaired psychomotor performance but there was not significantly greater impairment with high dose possibly due to the learning phenomenon of psychomotor performance tests $^{20}$. While individual drug Nitrendipine, Diltiazem and Verapamil showed significant impairment of psychomotor performance but their results were not significantly different when compared amongst themselves.

In conclusion- Nitrendipine, Diltiazem and verapamil in low dose and high dose impaired the psychomotor performance of human volunteers.

Although these agents are used safely most of the time by the patients in acute or chronic diseases at intervals of 8 to 12 hours over several days or weeks, Nitrendipine, Diltiazem and Verapamil in the dosage used are not very safe drugs for those who are engaged in tasks requiring higher skill and motor activity.

Therefore patients taking drugs which produce psychomotor impairment may be at risk or lapses and significant errors that may lead to potential hazards and decreased work productivity more specifically those involved in skilled work like driving vehicles, pilots and machine operators etc ${ }^{21-23}$.

Conflict of interest- None to declare

\section{Acknowledgement}

The author thanks Dr. Muhammad Mateenuddin, Professor and Head, Dept. of Pharmacology, Bidar Institute of Medical Sciences, Bidar (Karnataka, India) for his kind support.

Table No. 1

Effects of Calcium channel blockers on psychomotor performance in human volunteers Mean \pm S.E.M. * $(n=15)$

\begin{tabular}{|c|c|c|c|c|c|c|c|c|c|c|}
\hline & \multicolumn{10}{|c|}{ Psychomotor performance tests } \\
\hline & \multicolumn{2}{|c|}{ Arithmetic ability test } & \multicolumn{2}{|c|}{ Verbal learning test } & \multicolumn{2}{|c|}{ Letter cancellation test } & \multicolumn{2}{|c|}{$\begin{array}{l}\text { Digital symbol } \\
\text { substitution test }\end{array}$} & \multicolumn{2}{|c|}{ Card sorting test } \\
\hline $\begin{array}{l}\text { Treatment } \\
\text { group }\end{array}$ & $\begin{array}{l}\text { Pre } \\
\text { treatment } \\
\text { score }\end{array}$ & $\begin{array}{l}\text { Post } \\
\text { treatment } \\
\text { score }\end{array}$ & $\begin{array}{l}\text { Pre } \\
\text { treatment } \\
\text { score }\end{array}$ & $\begin{array}{l}\text { Post } \\
\text { treatment } \\
\text { score }\end{array}$ & $\begin{array}{l}\text { Pre } \\
\text { treatment } \\
\text { score }\end{array}$ & $\begin{array}{l}\text { Post } \\
\text { treatment } \\
\text { score }\end{array}$ & $\begin{array}{l}\text { Pre } \\
\text { treatment } \\
\text { score }\end{array}$ & $\begin{array}{l}\text { Post } \\
\text { treatment } \\
\text { score }\end{array}$ & $\begin{array}{l}\text { Pre } \\
\text { treatment } \\
\text { score }\end{array}$ & $\begin{array}{l}\text { Post } \\
\text { treatment } \\
\text { score }\end{array}$ \\
\hline $\begin{array}{l}\text { Nitrendipine } \\
10 \mathrm{mg}\end{array}$ & $0.6 \pm 0.213$ & \begin{tabular}{l|}
$* *$ \\
$1.51 \pm 0.221$
\end{tabular} & $8.53 \pm 0.244$ & $\begin{array}{l}* * \\
7.58 \pm 0.275\end{array}$ & $54.33 \pm 2.19$ & $54.08 \pm 1.95$ & $9.6 \pm 0.288$ & $\begin{array}{l}* * \\
8.31 \pm 0.319\end{array}$ & $4 \pm 0$ & $\begin{array}{l}* * \\
3.42 \pm 0.107\end{array}$ \\
\hline $\begin{array}{l}\text { Nitrendipine } \\
20 \mathrm{mg}\end{array}$ & $0.46 \pm 0.132$ & \begin{tabular}{l|}
$* *$ \\
$1.38 \pm 0.282$
\end{tabular} & $9.06 \pm 0.252$ & $\begin{array}{l}* * \\
8.11 \pm 0.322\end{array}$ & $44.93 \pm 2.86$ & $44.27 \pm 2.13$ & $9.4 \pm 0.244$ & $\begin{array}{l}* * \\
9.21 \pm 0.126\end{array}$ & $3.93 \pm 0.066$ & $\begin{array}{l}* * \\
3.58 \pm 0.101\end{array}$ \\
\hline $\begin{array}{l}\text { Diltiazem } \\
30 \mathrm{mg}\end{array}$ & $1.06 \pm 0.140$ & \begin{tabular}{l|}
$* *$ \\
$1.75 \pm 0.148$
\end{tabular} & $8 \pm 0.337$ & $\begin{array}{l}* * \\
7.50 \pm 0.174\end{array}$ & $59.06 \pm 2.34$ & $59.37 \pm 1.88$ & $10 \pm 0$ & $\begin{array}{l}* * \\
8.84 \pm 0.370\end{array}$ & $3.6 \pm 0.130$ & $3.38 \pm 0.105$ \\
\hline $\begin{array}{l}\text { Dilitiazem } \\
60 \mathrm{mg}\end{array}$ & $1.06 \pm 0.205$ & $\begin{array}{l}* * \\
1.79 \pm 0.170\end{array}$ & $8.46 \pm 0.396$ & $\begin{array}{l}* * \\
7.58 \pm 0.177\end{array}$ & $49.73 \pm 2.92$ & $48.89 \pm 2.19$ & $9.86 \pm 0.090$ & $\begin{array}{l}* * \\
9.61 \pm 0.138\end{array}$ & $3.93 \pm 0.066$ & $\begin{array}{l}* * \\
3.60 \pm 0.126\end{array}$ \\
\hline $\begin{array}{l}\text { Verapamil } \\
40 \mathrm{mg}\end{array}$ & $2.06 \pm 0.298$ & $\begin{array}{l}* * \\
2.70 \pm 0.213\end{array}$ & $8.6 \pm 0.201$ & $\begin{array}{l}* * \\
8.01 \pm 0.209\end{array}$ & $51.13 \pm 2.24$ & $50.29 \pm 1.52$ & $9.6 \pm 0.248$ & $\begin{array}{l}* * \\
9.14 \pm 0.111\end{array}$ & $3.66 \pm 0.159$ & $3.46 \pm 0.099$ \\
\hline $\begin{array}{l}\text { Verapamil } \\
80 \mathrm{mg}\end{array}$ & $1.73 \pm 0.352$ & \begin{tabular}{l|}
$* *$ \\
$2.74 \pm 0.182$
\end{tabular} & $8.86 \pm 0.284$ & $\begin{array}{l}* * \\
7.92 \pm 0.255\end{array}$ & $43.6 \pm 2.06$ & $44.19 \pm 1.80$ & $9.86 \pm 0.133$ & $\begin{array}{l}* * \\
9.21 \pm 0.120\end{array}$ & $4 \pm 0$ & $\begin{array}{l}* * \\
3.54 \pm 0.121\end{array}$ \\
\hline
\end{tabular}

*Standard error of mean. ** Statistically significant $(\mathrm{p}<0.05)$ 


\section{References:}

1. Donald A W. Calcium channel blockers. In: cardiovascular pharmacotherapy I. Medical Clinics of North America. Jan. 1988; 72(1): 83-106

2. Dolin S G and Little H J. Augmentation by calcium channel antagonists of general anaesthetic potency in mice. Br. J. Pharmac. 1986; 88:909$914 \mathrm{http} / / / \mathrm{dx}$.doi.org/10.1111/j.1476 5381.1986.tb16265.xPMid: 2943355 PMCid:1917075

3. George P M and Ramchandran J. Antagonists of neuronal calcium channels: structure, function and therapeutic implications. Annual Review of Pharmacology and Toxicology 1995; 35: 707734http://dx.doi.org/10.1146/annurev.pa.35.040 195.003423PMid:7598513

4. Godfraind T, Miller R and Wibo M. Calcium Antagonism and Calcium Entry Blockade. Pharmacol. Review 1986; 38: 324-427

5. Cyril Hoschi. Do calcium antagonists have a place in the treatment of mood disorders? Drugs 1991; 42(5): 721-729 http://dx.doi.org/10. $2165 / 00003495199142050-00001$ PMid:1723370

6. Snyder S H, Reynolds I J. Calcium antagonists drugs. The New England Journal of Medicine. Oct. 1985;313 : 995-1002PMid:2413355

7. Doran A R, Narang P K. Meigs C Y etal. Verapamil concentrations in cerebrospinal fluid after oral administration. The New England Journal of Medicine. 1985;312 (19): 1261-1262 http://dx.doi.org/10.1056/NEJM198505093121 920

8. Seth S D and Seth S. Calcium channels and Calcium channels blockers. Indian J. Physiol Pharmacol. 1991; 35(4); 217-231 PMid:1667398

9. Jaguste V S, Dadkar V N, Dhar H L. Effects of Verapamil and Nifedipine on psychomotor performance in human subjects. JAPI 1991; 30(6): 457-462

10. Clubley M, Bye C E, Henson T A, Peck A W and Riddington $\mathrm{C}$ J. Effects of caffeine and cyclizine alone and in combination on human performance, subjective effects and EEG activity. Br. $J$. clin. Pharmac. 1979; 7: 157-163

11. File S E, and Lister R G. A comparison of the effects of lorazepam with those of propranolol on experimentally induced anxiety and performance. Br. J. clin. Pharmac. 1985; 19: 445-451

12. Tansella C Z, Tansella M and Lader M. A comparision of the clinical and psychological effects of diazepam and amylobarbitone in anxious patients. Br. J. clin. Pharmac. 1979; 7: 605-611

13. Khajuria V, Kapoor B and Raina R K. Studies on psychomotor performance in healthy volunteers after diazepam, propranolol and alcohol given alone and in combination. Indian $J$ physiol Pharmacol. 1995; 39(3): 242-246 PMid:8550117

14. Salkind M R, Hanks G W, Silverstone J T. Evaluation of the effects of clobazam, A 1,5 benzodiazepine, on mood and psychomotor performance in clinically anxious patients in general practice. Br. J. clin. Pharmac. 1979; 7: 113S$118 \mathrm{~S}$

15. Balakrishnan S, Bhargave U K, Pandhi P. Anticonvulsant and psychomotor activity of Nitrendipine alone and in combonation with phenytoin and valproate in rats. Methods find. exp. Clin. Pharmacol. Jul- Aug. 1999; 21 (6): 441-447http://dx.doi.org/10.1358/mf.1999. 21.6.541926PMid:10445238

16. Skinner $M$, Futterman A, Mirrissette D, Thompson L W, Hoffman B B, Blaschke T F. Atenolol compared with Nifedipine: effect on cognitive function and mood in elderly hypertensive patients. Ann. Intern. Med. Apr. 1992; 116(8): 615- 623PMid: 1546860

17. Spurgeon D. Calcium channel blockers affect cognitive function in older people. BMJ Sept. 1999; 319: 806 http://dx.doi.org/10. 1136/bmj.319.7213.806b PMCid:1116663

18. Maxwell C J, Hogan D B, Ebly E M. Calcium channel blockers affect cognitive function in 
older people: results from the Canadian study of health and aging. CMAJ Sept. 1999; 16195): 501- 506

19. Payne R. Medication induced performance deficits analgesics and narcotics. J. Occup. Med. Apr.1990; 32(4): 369 http://dx.doi.org/10.1097/00043764199004000-00018 PMid:1970835

20. Wetherell A. Cognitive and psychomotor performance tests and experiment design in multiple chemical sensitivity. Eviron. Health perspect 1997; 105(2): 495S- 503S http://dx.doi.org/10. 1289/ehp.97105s2495

21. Kay G G, Berman B, Mockviak S H et al. Initial and steady state effects of diphenhydramine and loratidine on sedation, cognition, mood and psy- chomotor performance. Arch. Intern. Med. Nov. 1997; 157(20): 2350- 2356 http://dx.doi org/10.1001/archinte.1997.00440410082009 PMid:9361576

22. Adelsberg, B R. Sedation and performance issues in the treatment of allergic conditions. Arch. Intern. Med. Nov. 1997; 157(5): 494- 500 h t t p : / / d x.doi . org / 10.1001 / a r c h inte.1997.00440260028006PMid:9066452

23. Hakkou F, Jaouen C, Iraki L. A comparative study of cyproheptadine and DL carnitine on psychomotor performance and memory in healthy volunteers. Fundam. Clin. Pharmacol. 1990; 4(2): 191-200 http://dx.doi.org/10. $1111 /$ j. $1472-8206.1990$.tb 00487 .x PMid:2351368 